\title{
Direitos Humanos e gênero no cenário da migração e do tráfico internacional de pessoas*
}

\author{
Asbrad $^{* *}$
}

Resumo

Este texto apresenta algumas observações sobre as violações de direitos humanos que têm lugar na migração internacional e no tráfico de pessoas a partir dos relatos de mulheres migrantes abordadas pela equipe do Posto de Atendimento Humanizado aos/às Migrantes, no aeroporto internacional de Guarulhos. A apresentação desses casos mostra a violação de direitos nesse contexto e a importância de se discutir o enfrentamento ao Tráfico de Pessoas a partir de uma perspectiva de gênero e Direitos Humanos.
\end{abstract}

Palauras-chave: Tráfico de Pessoas, Migração, Gênero, Mulheres.

\footnotetext{
* Recebido para publicação em setembro de 2008, aceito em outubro de 2008.

** Associação Brasileira de Defesa da Mulher, da Infância e da Juventude. Este texto foi produzido pela equipe do Posto de Atendimento Humanizado aos/às Migrantes: Dalila Eugênia Maranhão Dias Figueiredo, Débora Donadel, Elizângela André dos Santos, Marina Gurgel Neves e Marly Françoso. asbradguarulhos@terra.com.br
}

cadernos pagu (31), julho-dezembro de 2008:251-273. 
Direitos Humanos e gênero

Human Rights and Gender in the Scenario of Migration and International Trafficking in Persons

\begin{abstract}
This paper presents some comments about violations of human rights taking place in international migration and human trafficking from the reports of migrant women gathered by the team of the Posto de Atendimento Humanizado aos/às Migrantes, in the International Airport of Guarulhos. The presentation of these cases shows the violation of rights in that context and the importance of discussing the confrontation with Trafficking in Persons from a perspective of gender and Human Rights.
\end{abstract}

Key Words: Trafficking in Persons, Migration, Gender, Women. 
Asbrad

\section{Apresentação}

O presente texto descreve violações dos direitos humanos a partir de narrativas de mulheres migrantes abordadas pela equipe do Posto de Atendimento Humanizado aos/às Migrantes, que desde dezembro de 2006 atende brasileiros/as que retornam ao Brasil, via Aeroporto internacional de Guarulhos, como deportados/as e inadmitidos/as. ${ }^{1}$

Esse Posto foi criado a partir da experiência de atendimento voluntário a vítimas do tráfico de pessoas, iniciada em 1999 pela Associação Brasileira de Defesa da Mulher, da Infância e da Juventude (Asbrad). O serviço ganhou contornos mais concretos a partir do resultado de duas pesquisas realizadas, respectivamente, em 2005 e 2006 ${ }^{2}$, numa parceria entre a Secretaria Nacional de Justiça do Ministério da Justiça, o Escritório das Nações Unidas contra Drogas e Crime (UNODC) e a Organização Internacional do Trabalho (OIT). As duas investigações buscaram apreender indícios da existência de vítimas do tráfico de pessoas entre os brasileiros e brasileiras que retornavam ao país via aeroporto de Guarulhos na condição de deportados/as ou não-admitidos/as. No final de 2006, graças ao apoio financeiro da Cordaid ${ }^{3}$ -

1 Deportados são aqueles que moram em um outro país e são "devolvidos" por terem ultrapassado o período de permanência concedido pela autoridade migratória, ou por terem cometido algum tipo de infração. Já a inadmissão acontece quando a autoridade estrangeira recusa o ingresso no país de destino, geralmente por desconfiar de uma potencial imigração irregular. Tal atitude é legitimada pela soberania do país.

2 No primeiro semestre de 2005 foi realizada a pesquisa "Indícios de Tráfico de Pessoas no Universo de deportadas e inadmitidas que regressam ao Brasil via Aeroporto Internacional de Guarulhos" e, em novembro de 2006, a pesquisa "Tráfico Internacional de Pessoas no universo de homens, mulheres $e$ transgêneros deportados/as que retornam ao Brasil via aeroporto Internacional de Guarulhos", ambas coordenadas pela antropóloga Adriana Piscitelli (Secretaria Nacional de Justiça, 2006; 2007).

3 Cordaid é uma organização social que se empenha no combate duradouro à pobreza em mais de 40 países da África, Ásia, América Latina, Oriente Médio, Europa Central e Oriental e Holanda. Sediada em Haia, Holanda, a organização 
Direitos Humanos e gênero

organização humanitária holandesa, do apoio institucional do Ministério da Justiça e do Escritório das Nações Unidas contra Drogas e Crime (UNODC) - foi possível colocar em funcionamento o serviço mediante a execução de um projeto piloto. Através do trabalho de identificação e apoio a vítimas desse tipo de tráfico, o objetivo desse projeto foi elaborar uma metodologia de atendimento para essas pessoas, especialmente mulheres vulneráveis ao tráfico ou traficadas.

O Posto de Atendimento Humanizado aos/às Migrantes tem como objetivo contribuir para um atendimento humanizado $e$ efetivo a essas pessoas, com especial atenção para as possíveis ${ }^{4}$ vítimas de Tráfico de Pessoas. O caráter humanizado do serviço reflete a adoção do paradigma de promoção dos direitos humanos, os princípios do Protocolo de Palermo e a experiência acumulada da Asbrad na temática de violência de gênero, possibilitando, assim, uma abordagem singular e diferenciada em um local onde os temas migração e tráfico de pessoas se encontram - Aeroporto Internacional de Guarulhos. O trabalho de acolhimento, apoio e orientação, na área de acesso restrito, foi realizado pela equipe multidisciplinar da Asbrad.

O público-alvo da abordagem são mulheres e "trans" ${ }^{5}$ que retornam ao Brasil como deportadas e inadmitidas. No caso das mulheres, a maioria vem em vôos originários da Espanha, Estados Unidos, Inglaterra e Portugal.

$\mathrm{Na}$ dinâmica do Aeroporto, as pessoas inadmitadas $e$ deportadas são separadas dos demais passageiros, enquanto seus

surgiu em 1999 a partir da fusão das organizações católicas de desenvolvimento - Memisa, Mensen in Nood e Bilance (Vastenaktie e Cebemo).

4 "possíveis" vítimas de tráfico está aspeado porque, entre aquelas que relatam suas histórias, não necessariamente se tratam de pessoas traficadas. Além disso, são abordadas também pessoas que apresentaram indícios de terem sido traficadas, mas não quiseram, ou não puderam, relatar suas histórias.

5 Segundo a pesquisadora Adriana Piscitelli, "trans" é um termo êmico freqüentemente utilizado para aludir ao conjunto de pessoas consideradas travestis, transexuais ou transgêneros. 
documentos são verificados pela Polícia Federal. Durante a espera pela liberação, elas são abordadas pela equipe do Posto, que se apresenta como uma organização não governamental de Direitos Humanos e pergunta sobre o tratamento dispensado a elas no exterior. A partir desse contato - respeitando sempre o consentimento da atendida -, inicia-se um diálogo, origem dos relatos aqui apresentados.

Acolher, apoiar e orientar na maior fronteira aérea brasileira não é tarefa simples, considerando que o aeroporto é visto como um lugar de mínima permanência possível, um local de passagem. No entanto, apesar dessa dificuldade, são muitas as pessoas deportadas e inadmitidas que querem contar suas histórias, que mencionam superações, sonhos ainda não realizados e também direitos violados. Essas violações de direitos estão associadas não apenas à condição de migrantes, mas, principalmente, a estereótipos relacionados com país de origem, gênero, orientação sexual e ocupação.

O trabalho realizado pelo Posto de Atendimento Humanizado aos/às Migrantes não tem caráter de pesquisa. Tratase de uma experiência pioneira que contribui para uma reflexão sobre a legislação brasileira, o Protocolo de Palermo e a autonomia das mulheres migrantes, ampliando a discussão dos temas tráfico de pessoas e gênero.

No primeiro ano de atuação do Posto de Atendimento Humanizado aos/às Migrantes, o Posto abordou 2088 pessoas, 800 mulheres, 41 "trans". Foram abordadas 63 pessoas que apresentaram indícios de tráfico de pessoas, sendo 42 mulheres e 16 "trans".

Para a elaboração deste texto foram escolhidos relatos de diversas mulheres deportadas e não admitidas atendidas, entre eles, quatro casos que mostram indícios de tráfico de pessoas. $\mathrm{O}$ conjunto de narrativas remete a diferentes violações de direitos humanos.

A apresentação desses casos evidencia a ausência de um "modelo de vítima" e mostra a importância de discutir o 
Direitos Humanos e gênero

enfrentamento ao Tráfico de Pessoas a partir de uma perspectiva de Direitos Humanos que considere as mulheres

como sujeitos atuantes, auto-determinados e posicionados de maneira diferente, capazes não só de negociar $e$ concordar, mas também de conscientemente opor-se e transformar relações de poder, estejam estas enraizadas nas instituições de escravidão, prostituição, casamento, lar ou mercado de trabalho (Kempadoo, 2005:61-62).

\section{Discriminação e controle migratório}

A discriminação de gênero no país de destino aparece com freqüência nas narrativas das mulheres deportadas e inadmitidas, que dizem terem sido tratadas como prostitutas $e$ por isso discriminadas, não só por funcionários de migração, mas também pelos cidadãos estrangeiros.

No caso das pessoas inadmitidas, percebe-se a ausência de critérios para o impedimento de entrada no país de destino, o que abre brechas para o abuso de autoridade e ações discriminatórias. É freqüente, por exemplo, a recepção de pessoas que foram inadmitidas por portarem pouco dinheiro. $\mathrm{O}$ argumento da polícia migratória estrangeira, principalmente a de países europeus, é que a pessoa sem dinheiro torna-se "vulnerável". Assim, a devolução dessas pessoas ao país de origem teria o caráter de "proteção" ao viajante.

No entanto, nos relatos das pessoas abordadas, essas ações aparecem como controle migratório. Para a polícia de fronteira, quem não tem recursos financeiros é um/a possível migrante irregular e por isso será inadmitido/a. No caso das mulheres, além de migrante irregular, é corrente a idéia de que elas buscariam na indústria do sexo uma maneira de se manter no país de destino.

Uma das mulheres inadmitidas disse que os policiais no aeroporto de Milão insinuaram o tempo todo que ela estava indo para se prostituir (Relatório, 21 de fevereiro de 2007). 
A inadmitida em Madri, 49 anos, de Joinville/SC, não entrou porque os policiais questionaram o fato de ela ser casada (e com 3 filhos) e buscar hospedagem na casa de um amigo do marido em Barcelona. Professora universitária, de classe média, estava muito chateada. Disse que sofreu revista íntima, (por mulheres), e que entendia as piadinhas que os policiais faziam (...) dando a entender que era mais uma prostituta (Relatório, 07 de março de 2007).

mulher (...)51 anos, natural de Inhumas - GO, inadmitida em Londres, via Madrid (...) Foi com o neto e com a amiga (...) visitar a filha, que é imigrante irregular. Por medo de que a descobrissem, não quiseram chamá-la no aeroporto. $\mathrm{Me}$ mostrou o papel da polícia londrina que dizia que o motivo da deportação era a intenção de realizar práticas não consideradas legais pelas leis migratórias, sem especificar quais práticas seriam essas. Disseram que o motivo da deportação era o fato de não apresentar reserva de hotel (...)

[Disse para a atendente] "como poderia fazer prostituição se já não sou mais mocinha?", pois a sensação que tinha era a de que haviam evitado sua entrada em Londres por isso (Relatório, 02 de fevereiro de 2007).

Contou que um policial insinuou que ela iria se prostituir em Londres. "Falei para o intérprete dizer ao policial que me visitasse quando fosse o Brasil para ver que sou mulher decente". Disse que o policial ficou constrangido e pediu desculpas, mas não desistiu da inadmissão (Relatório, 16 de maio de 2007).

São relatos de mulheres que, em última instância, foram inadmitidas por terem sido consideradas prostitutas. $\mathrm{O}$ discurso antitráfico ${ }^{6}$ que relaciona tráfico de pessoas à prostituição fortalece tais ações antimigratórias e xenofóbicas.

\footnotetext{
${ }^{6}$ A imprensa brasileira retrata a visão européia da mulher brasileira em manchetes como "Europa tem 75 mil prostitutas do Brasil" (O Estado de S.Paulo, caderno Metrópole, página $\mathrm{C} 1,18$ de maio de 2008) e "Brasileira = Prostituta. É assim que a Europa nos vê" (Claudia, maio 2008, pp.130-131). Relaciona, ainda, a prostituição ao tráfico de pessoas, sem discutir o Protocolo de Palermo.
} 
Direitos Humanos e gênero

\section{Migração e gênero}

O enfrentamento ao tráfico de pessoas não pode

ignorar as razões para migrar $e$ as necessidades e desejos das pessoas de deixarem seus países para melhorar de vida, mesmo que isso envolva ser contrabandeado e trabalhar em condições deploráveis no comércio sexual. Isso conduz a fugir do problema da atuação e autodeterminação dos migrantes e leva, portanto, a métodos e estratégias não adequados às necessidades deles (Kempadoo, 2005:69).

É preciso compreender as motivações das mulheres que decidem migrar para a criação de uma política efetiva de proteção à mulher migrante, que não impeça seu desejo de migrar e que propicie auxílio a suas reais necessidades.

A busca por melhores condições de vida, mesmo enfrentando incertezas, é recorrente nas narrativas das migrantes. São relatos de mulheres que aparecem como sujeitos autônomos em busca de melhores condições de vida para si e para sua família (Lisboa, 2006:151-152).

A maioria das mulheres atendidas viajava sem a certeza de conseguir um emprego, formal ou informal, no país de destino, contando apenas com algum parente ou amigo que, possivelmente, poderia the arrumar um emprego no país de destino. Elas relatam ter se ocupado em atividades de limpeza (como diarista em casas particulares, hotéis e restaurantes), cuidando de crianças e idosos, trabalhando na agricultura, no comércio, como dançarinas ou envolvidas na indústria do sexo.

As motivações para migrar, porém, não se reduzem a causas sócio-econômicas. Os relatos de três mulheres que tiveram a experiência de migrar e retornaram ao Brasil como deportadas e inadmitidas mostram a importância das dimensões subjetivas. Ao narrar suas histórias de vida, apontam para diferentes motivações para a migração, desde o desejo de não mais morar na zona rural até a fuga de um marido ou um pai violento. 
mulher, 32 anos, natural de Goiânia-GO, deportada da Espanha, onde morava há 2 anos. Estava nervosa, passando mal e não queria falar. Pediu ajuda no preenchimento da ficha da $\mathrm{PF}^{7}$, mas disse que não tinha "nada a declarar" como objetivo da viagem. Falava com a mão sobre a boca e estava assustada. Disse que preferia aguardar um vôo que saísse só no dia seguinte, de Guarulhos, a ter que pegar um ônibus para o outro aeroporto. "Aqui é muito perigoso, eu sei". Tentamos acalmá-la. Falou que a mãe mora em (...) uma fazenda e ela não queria morar em fazenda. Por isso foi para Goiânia $e$ depois para a Espanha (...) (Relatório, 17 de abril de 2007).

mulher, 45 anos, (...) deportada de CopenhagenDinamarca. Contou que mora com a filha e o neto em Copenhagen há mais de 3 anos. (...) Disse que precisava vir ao Brasil para finalizar seu divórcio pois tinha a intenção de casar-se com um dinamarquês ainda este ano. Falou também que precisava voltar para apaziguar a relação entre o filho e o ex-marido, que voltaram a morar juntos. $\mathbf{0}$ exmarido a espancava $e$ o filho presenciava. Mostrou marcas de ferimentos que ainda estão em seu corpo. Foi vítima de violência doméstica por muitos anos. (...) (Relatório, 16 de maio de 2007).

$\mathrm{Na}$ narrativa a seguir, de uma brasileira inadmitida em Lisboa, aparece uma série de situações violentas - a figura de um pai violento, um namorado pedófilo e uma cidade preconceituosa - que, desde a infância, estimulou seus deslocamentos. Seu desejo de continuar migrando está relacionado também à imagem que os moradores da pequena cidade, da qual é originária, faz da mulher migrante.

mulher, 28 anos, natural do estado do Pará, inadmitida em Lisboa. Chegou revoltada, dizendo que havia sido tratada

\footnotetext{
7 Nas abordagens realizadas em 2008 não se verificou o uso dessas fichas pela Polícia Federal.
} 
Direitos Humanos e gênero

como traficante de drogas e que havia sido revistada por policiais para saber se levava drogas no corpo. Perguntei se tais policiais eram mulheres, disse que sim.

Contou que apanhava de seu pai quando criança e por isso saiu de casa aos 12 anos.(...).

Contou que já havia morado na França e na Guiana Francesa e que nunca havia tido problemas. Um pouco depois, contou que havia sido deportada para Belém da Guiana. (...) Falei abertamente sobre tráfico de pessoas e ela disse que não havia passado por isso.

Contou que quando morava na Guiana, conheceu um espanhol que a levou para morar na França. Ficou lá 2 anos, morando com a filha, então com 7 anos. Quando estava prestes a se casar "só para pegar os papéis, porque eu não gostava dele", descobriu que ele era pedófilo e se masturbava vendo a criança.

Fugiu e disse que foi jurada de morte.

Hoje a menina mora com a tia, no Pará. Ela me disse, chorando, que queria sair de lá com a filha, pois "a cidade acha que só porque eu ganhei alguma coisa, eu sou traficante ou prostituta". Não queria que a filha passasse por esse constrangimento.

(...) Ao contatar a família, descobriu que seu ex-marido estava querendo a guarda de sua filha (Relatório, 04 de setembro de 2007).

Uma vez no exterior, em certos países, essas migrantes não se livram do fantasma da prostituição:

Disse que as brasileiras em Portugal são vistas como prostitutas, sem exceção. Contou ter sido abordada várias vezes por europeus convidando-a para fazer programas, mas recusou todas as ofertas. Segundo ela, alguns desses convites foram realizados na presença do marido, que ficou muito constrangido. Lá em Portugal, um grupo de jovens que estava em um carro gritou em pleno centro comercial da cidade: "brasileira, puta!". Ela disse que as pessoas próximas imediatamente se voltaram para a direção em que 
estava, fuzilando olhares de reprovação (Relatório, 27 de março de 2007).

Percebendo essa dinâmica excludente, algumas mulheres dizem sentirem-se mais seguras quando não apresentam as características atribuídas ao estereótipo da mulher brasileira. O relato de uma mulher de 33 anos, deportada da Suíça, que se percebe distante desse estereótipo, exemplifica esse ponto.

(...) Chegou revoltada, chorando e mal dizendo o Brasil. Queria poder nunca mais voltar. (...) Já havia morado na Espanha, na Itália e na França. Estava há 11 anos na Europa. Foi pega na estação de trem, quando voltava para casa. Trabalhava com instalação elétrica. (...) Namora um italiano e está com casamento marcado para agosto (...) A primeira vez que foi para a Europa, seu destino era a Espanha. (...) Contou também que na Espanha era freqüentemente confundida com uma cubana. "Diziam que eu não parecia brasileira, porque brasileira tem que ter curvas e ser sexy e eu tenho esse jeito meio machinho. Assim é mais seguro" (Relatório, 04 de setembro de 2007).

A situação pode ser mais violenta quando se trata de migrantes irregulares, de fato, envolvidas na indústria do sexo, como no relato a seguir.

Foi agredida fisicamente por policiais da imigração espanhola, por ocasião de sua estadia no centro de imigração em Valença/Espanha. Segundo ela, um policial tentou fazer carícias sendo repelido. Como represália ele a espancou usando um cacetete [barra de ferro] desferindolhe golpes nas nádegas, com o auxílio de outro policial que a segurou pelos cabelos (Relatório, 09 de março de 2007).

Esse relato evoca as afirmações de Kamala Kempadoo (2005:64) sobre a posição ocupada pelas migrantes que trabalham na indústria do sexo. Segundo a autora, a criminalização da 
Direitos Humanos e gênero

prostituição exacerba a violência que as mulheres migrantes experimentam nas mãos de recrutadores, contrabandistas, empregadores, polícia, funcionários da imigração ou carcereiros de centros de detenção, cadeias ou prisões, entre os quais o triplo estigma - criminosa, puta e imigrante - promove intenso desrespeito e tratamento desumano.

\section{Indícios de tráfico em narrativas de mulheres atendidas pelo Posto de Atendimento Humanizado aos/às Migrantes}

Os relatos a seguir são de mulheres que apresentaram indícios de tráfico internacional de pessoas, identificados a partir da abordagem da equipe do Posto de Atendimento Humanizado aos/às Migrantes.

Cabe ressaltar que o Posto trabalha em consonância com o que preconiza o Protocolo de Palermo.

Ao optar pelas diretrizes do Protocolo de Palermo, a equipe do Posto não considera o trabalho na indústria do sexo suficiente para identificar uma pessoa como traficada. Ou seja, não considera a prostituição em si como uma violência contra as mulheres. Como aponta Kempadoo (2005:62)

(...) são as condições de vida $e$ de trabalho em que as mulheres podem se encontrar no trabalho do sexo, e a violência $e$ terror que cercam esse trabalho num setor informal ou subterrâneo que são tidos como violadores dos direitos das mulheres $e$, portanto, considerados como "tráfico".

Os quatro casos descritos a seguir diferem entre si $e$ demonstram que os indícios de tráfico não remetem a um modelo idealizado de "vítima de tráfico de pessoas".

No primeiro caso, duas mulheres foram enganadas na busca por um marido estrangeiro, com o fim de serem exploradas no trabalho doméstico. 
Elas chegaram em Amsterdã da mesma forma: entraram num site na procura de marido estrangeiro e acabaram por manter contato com uma mulher que lhes ofereceu emprego. Aceitaram, pegaram dinheiro emprestado com amigos e familiares e foram. Chegando lá não recebiam pelo trabalho feito nas casas, diferente do combinado com a mulher. Ficaram de dois a três meses nessas condições. Quando conseguiram abandonar essa situação, sofreram perseguição da aliciadora até serem deportadas.

Uma delas (...) tinha 40 anos e se mostrou bastante disposta a falar (...) não tinha muita consciência da gravidade do que tinha vivido. A outra mulher de 49 anos (...) mostrou-se retraída. Passava o tempo todo afastada, prestando atenção no que a outra dizia e quando fui falar com a mesma posicionou-se com respostas rápidas e curtas (...) (Relatório, 18 de janeiro de 2007).

No segundo relato, uma mulher é enganada sobre o trabalho que iria realizar na Suíça. A promessa era um emprego de garçonete, mas chegando à Zurique teve seus documentos retidos e foi obrigada a prostituir-se. Neste caso, a atendida considera ter sofrido abusos e ser vítima de tráfico de pessoas. No entanto, ainda que não se percebesse dessa maneira, sua fala apontava para diversos indícios de que ela tenha sido vítima de tráfico.

Há o engano ("...disse que poderia levá-la à Suíça para trabalhar em um restaurante ganhando 5 mil francos por mês"); o cárcere privado; o passaporte retido; a exploração; a dívida e sua manutenção; a coação ("...filho de 8 anos sofrer um seqüestro em sua cidade natal, armado pelas pessoas da quadrilha que a levaram para a Suíça"); o constrangimento (foi mal falada na cidade de origem por não ter pagado a dívida). 
Direitos Humanos e gênero

Apesar desses indícios e da denúncia feita à polícia portuguesa, ela não foi tratada como vítima, sendo deportada após ser denunciada como imigrante irregular. ${ }^{8}$

Retornou ao Brasil como deportada de Portugal, onde morava há quase um ano e meio. Conforme seu relato, depois de duas semanas sendo explorada sexualmente, conseguiu fugir com a ajuda de um português e fixou-se na llha dos Açores.

Livre do cárcere privado, voltou a trabalhar "com sexo", pois se sentia na obrigação de enviar dinheiro para o Brasil - onde sua mãe cuidava de seu filho. Contou ainda que a família nunca soube de seu trabalho, nem mesmo do período em que foi traficada.

mulher, 30 anos, natural do estado de Goiás, deportada de Lisboa. Morava em Portugal há 1 ano e 5 meses, na Ilha dos Açores, mas quando saiu do Brasil seu destino era Zurique. Perguntei se trabalhava em Portugal e me disse que não fazia nada, tinha um noivo português $e$ iam se casar. (...) contou que havia trabalhado "com sexo" antes, mas que já havia parado. A acompanhei até a esteira de bagagem. Sua mala chegou muito danificada.

Fiquei com ela na fila do balcão de reclamações. Nesse momento, me contou que achava que alguém a havia denunciado para a polícia migratória, porque na casa em que estava quando a polícia chegou havia outros brasileiros, no entanto chegaram perguntando por ela. Comentou que achava que poderia ser um antigo cliente, já que usava seu nome verdadeiro quando era trabalhadora sexual, e foi por esse nome que a procuraram. Perguntei se tinha alguém que poderia querer denunciá-la, por exemplo, alguém que a tivesse ajudado a viajar. Ela me disse que foi

\footnotetext{
8 "Além da prisão, detenção e deportação, como modos imediatos de disposição das mulheres, homens, meninas e meninos objetos de tráfico nos países de destino, essas pessoas, quando 'resgatadas', são em geral devolvidas aos países de origem como migrantes sem documentos, e têm de enfrentar a vergonha e a humilhação que acompanha tal categorização e o status de deportada" (Kempadoo, 2005:68).
} 
para a Europa via Suíça com uma mulher de sua cidade natal que trabalhava com tráfico de pessoas. Ela usou exatamente esse termo! E começou a contar sua história (...).

A mulher, chamada C., disse que poderia levá-la à Suíça para trabalhar em um restaurante ganhando 5 mil francos por mês. "Isso era muito dinheiro". Chegou em Zurique às 11 da manhã e a C., um português chamado M. e uma mulher romena disseram a ela que descansasse até às $4 \mathrm{da}$ tarde, que depois ela conheceria o restaurante. C. a acordou mais cedo que o combinado e a arrumou. "Eu não entendi porque ela estava me vestindo daquele jeito, mas pensei: "aqui eles devem trabalhar assim"'. Foi levada a uma sala, onde estavam 7 moças "seminuas". Disse que perguntou para C. se ali era mesmo um restaurante: "e ela me contou que não, que ali era uma casa de sobe e desce". Ela foi explorada sexualmente durante 16 dias, antes de fugir para Portugal. Contou que os clientes pagavam 80 Euros por programa e era exatamente esse valor que era cobrado pela diária do quarto que elas usavam. "Para comer, a gente tinha que ficar com mais de um cliente por noite". Disse que até hoje a família não sabe que ela passou por isso, apesar do filho de 8 anos sofrer um seqüestro em sua cidade natal, armado pelas pessoas da quadrilha que a levaram para a Suíça. Comentou depois que a aliciadora andou dizendo em sua cidade natal que ela era caloteira $e$ que não tinha pagado a passagem. A passagem custou 3 mil reais. Quando chegou em Zurique, disseram a ela que a dívida era de 3 mil francos. Ela fugiu sem pagar por nada. "O único dinheiro que eu dei para ela foi uns 500 Euros, para algumas despesas".

Ela relatou que quando foi pega pela polícia de imigração, contou sua história e denunciou os traficantes, dando nomes e endereços, mas a polícia portuguesa não acreditou. Ela ficou detida por 3 dias antes de ser deportada, sem ser ouvida como testemunha, nem considerada vítima. (...) ela mostrou vários hematomas nas pernas que, segundo ela, eram resultado dos maus tratos da 
Direitos Humanos e gênero

polícia portuguesa nos 3 dias que ficou detida em um presídio comum (...)

Contou sobre sua fuga: descobriu que uma das meninas que estava na "casa de sobe e desce" era sua conterrânea $e$ tinha ido à Zurique enganada, assim como ela. Estava lá fazia 6 meses e não estava ganhando dinheiro nenhum com seu trabalho. Elas decidiram juntar-se para fugir. Contou que certo dia que os "chefes" saíram para beber, ela e a amiga conseguiram pegar de volta seus passaportes. Ficaram alguns dias com o passaporte antes de fugir com a ajuda de um português que as transportou até Portugal em um caminhão. Foi logo depois da fuga que seu filho, de 8 anos de idade, foi seqüestrado na porta da escola. "Eles fizeram isso para me dar um susto, mas eu bati o pé dizendo que não pagaria a passagem $e$ os denunciaria".

Disse que a família não queria que ela viajasse, mas quando estava lá começaram a cobrar que ela enviasse dinheiro. Com vergonha de contar o que havia acontecido, continuou na Europa. (...) Namora um português há mais de um ano. Contou que estão com o casamento marcado para final do mês (...).

Acrescentou que a tal aliciadora ainda mora em sua cidade natal. Perguntei se essa cidade era grande o suficiente para elas não se encontrarem, e ela disse que não. Expliquei que existia uma rede de proteção à mulher e que os endereços que eu estava passando eram de lugares que poderiam ajudá-la se necessário: caso quisesse continuar a denúncia, por exemplo. Como a família não sabe de sua história e ela imagina que a denúncia a exporia, ela me disse que esperava que a polícia portuguesa resolvesse o caso (...) (Relatório, 03 de abril de 2007).

O caso a seguir traz uma situação de aliciamento que aconteceu no país de destino. A atendida viajou para a Espanha a convite de uma amiga, mas não conseguiu arranjar o emprego esperado. Conhece um estrangeiro e é enganada por ele com uma promessa de trabalho doméstico. É levada para a Dinamarca, 
onde é obrigada a se prostituir, sob a ameaça da família ser morta, caso se negasse.

A casa de prostituição onde era mantida foi descoberta pela polícia e ela foi acolhida por uma organização não governamental local. Contou que teve direito de permanência na Dinamarca. "Entretanto, não tinha pleno direito de ir e vir, e não poderia exercer qualquer atividade laboral naquele país, caso contrário teria o direito de permanência suspenso e conseqüentemente seria deportada".

Nos dez dias que ficou presa, antes de ser encaminhada à ONG, ela foi obrigada pelos policiais a mudar a cor de seus cabelos, pois "chamava muita atenção".

mulher, 27 anos, (...) Trata-se de uma jovem muito bonita, de estatura baixa, loira, e lentes de contato azuis. Desempregada (...) cursou apenas o ensino fundamental (incompleto), foi rejeitada pela mãe natural, tendo sido criada por outra família, (...), cuja situação financeira era muito precária. Na adolescência se encantou por (...) um chefe do tráfico de drogas. Com ele teve 02 filhos - um menino de oito anos de idade e uma menina de 02 anos de idade (...) Ela informou que o chefe do tráfico a sustentava (...) Sem possuir qualificação e estudo não conseguia emprego, por isso decidiu tentar a vida no exterior, se espelhando na tal amiga (bem-sucedida).

Com isso estava jurada de morte, não podendo regressar para sua cidade natal e seus filhos ficaram sob os cuidados e guarda da mãe e irmã (...).

Disse ter ido à Espanha (Madri) a convite de uma amiga (brasileira) casada com espanhol onde se hospedou. Tentou arrumar um emprego, mas não conseguiu, embora houvesse oferta para a prostituição - que ela descartava.

Em um café conheceu um homem de origem árabe, que falava espanhol com quem manteve amizade e vários encontros (...), ele passou a se interessar por seus relatos, declarando-se de família abastada e residente na Dinamarca, a qual poderia empregá-la como doméstica $e$ 
Direitos Humanos e gênero

assim regularizar sua situação na Europa. Ela aceitou a proposta combinando os detalhes da viagem, sendo que ele iria primeiro, a fim de preparar sua chegada; ela foi depois, só, de avião, com a orientação de que no aeroporto uma senhora morena a recepcionaria, como de fato ocorreu. Essa pessoa era brasileira, sem declinar maiores detalhes.

Ao chegar no apartamento "dele", o encontrou só, o que causou estranheza. Como desculpa disse que a família havia ido ao mercado fazer compras para recebê-la. O tal sujeito sugeriu que desfizesse suas bagagens, indicando o quarto $e$ pediu seu passaporte $e$ passagens sob o argumento de que os levaria imediatamente à pessoa responsável pelo contrato de trabalho, sendo entregues.

Horas depois o tal sujeito retornou com outras pessoas, dizendo o que se tratava e que iria para outro local. Ela se desesperou, mas precisou se conter quando ele pegou o celular e ligou para um número no Brasil - dizendo ter muitos amigos que dariam fim na família, caso ela lhe criasse algum problema. A ameaça surtiu efeito, pois ela temendo pela segurança de seus filhos e familia procurou não se rebelar.

Com isso foi levada para vários clubs e apartamentos para fazer programas, mas vinculada ao tal sujeito - cafetão que recebia porcentagens sobre seu faturamento, diferente de outras mulheres (algumas brasileiras) que circulavam livremente, enquanto ela ficava fixa, reclusa, escrava do tal árabe. (...) Perguntei se não saía do local de trabalho, respondendo que sim, para ir ao cabeleireiro, lojas, mercados, já que precisava se cuidar, mas sempre escoltada. Permitiam que enviassem dinheiro à família, algo em torno de $\mathrm{R} \$ 2.000,00$ (dois mil reais) ao mês, que serviu para a mãe sustentar os netos e reformar a casa, garantindo um pouco de conforto a eles.

Perguntei como foram descobertos, respondendo que a jovem responsável pela segurança se descuidou $e$ os policiais adentraram ao apartamento equipado com circuito de câmeras internas e externas, justamente para terem 
controle de tudo e todos, (...) foi presa, permanecendo 10 dias no Presídio, aguardando o julgamento.

Diante da informação, a interrompi explicando que em razão da existência de uma Lei Internacional (Protocolo) ela tinha o direito de permanecer lá, inclusive com um visto provisório por se tratar de vítima e por ter auxiliado as investigações informando com precisão o que ocorria, inclusive fornecendo nomes e atuações. Ela respondeu que em razão de sua colaboração poderia permanecer na Dinamarca por 03 meses, porém, aos cuidados da ONG dinamarquesa que a acolheu. Entretanto, não tinha pleno direito de ir e vir, e não poderia exercer qualquer atividade laboral naquele país, caso contrário, teria o direito de permanência suspenso e conseqüentemente seria deportada. Ela permaneceu na ONG por 03 semanas e 15 dias (...) Tratava-se de um recâmbio. (...) Quanto à situação na Dinamarca, destaco a informação de que durante o período em que ficou presa, foi obrigada a modificar a tonalidade de seus cabelos, que eram blond - loiríssimos, $e$ que, segundo os policiais, ela chamava muita atenção, sendo tingidos numa tonalidade mais cinza (...) (Relatório, 18 de julho de 2007).

Nos casos anteriores, a pessoa atendida não tinha conhecimento de que seria obrigada a se prostituir. Na narrativa a seguir, a mulher atendida já era profissional do sexo no Brasil, mas foi enganada sobre as condições de trabalho que encontraria na Espanha. Relembrando que, para o Protocolo de Palermo,

a questão do consentimento da vítima é irrelevante para caracterização do tráfico, uma vez que a vítima pode até ter concordado em trabalhar para a prostituição, mas jamais imaginou que seria escravizada, explorada sexual $e$ economicamente e violada em seus direitos fundamentais (Massula e Melo, 2003:18). 
Direitos Humanos e gênero

O engano não foi sobre o tipo de trabalho que seria realizado, mas sim em relação às condições.

Esse atendimento aconteceu a partir da solicitação de uma ONG espanhola.

(...) Retornou ao Brasil em vôo da companhia aérea Ibéria (...) A partir de solicitação de V. T. e uma ONG espanhola fomos recepcioná-la no Aeroporto Internacional de Guarulhos à 7:00h. Mantivemos contato com um delegado de seu Estado de origem, considerando a inexistência de serviços de atendimento para essa demanda $e$ considerando também a possibilidade da vítima manifestar o interesse de reiterar sua denúncia já concretizada na Espanha (...). A jovem retornou ao Brasil grávida de 4 meses. (...) viajou sem saber que estava grávida [sic] com proposta para trabalhar na prostituição e garantia de rendimentos semanais de cerca de 500 euros. De Bilbao foi levada para a Boite La Francia, próxima à praia. Alega que viajou logo que completou 18 anos porque se encontrava muito deprimida com a morte de seu genitor e após também uma forte discussão com seus familiares. Já tem uma menina de 2 anos com o mesmo pai biológico. Foi através do convite de uma amiga, que já tinha morado em sua casa, que resolveu aceitar a proposta. Entusiasmada, recebeu passagem, passaporte e 55 Euros para a viagem. Foi levada para Bilbao mas o Clube ficava em um povoado distante $200 \mathrm{~km}$. da cidade. Eram muitos quartinhos e lá também se encontravam outras 8 brasileiras, inclusive 3 da sua cidade. Soube que estava grávida e mesmo assim teve que manter relações sexuais para pagar a dívida contraída de cerca de 4000 Euros. Recebia empréstimo de 5 euros para ligar para a família 1 vez por semana. Era constantemente ameaçada e intimidada. "Outras também apanhavam". Não teve o passaporte retido, mas também não podia deixar o Clube por conta da dívida. Não suportando a humilhação ("só recebi um preservativo por dia"), após ter recebido um presente de um cliente, resolveu denunciar a organização criminosa à polícia 
espanhola, que fechou o local. Resolveu colaborar com as autoridades, mas não quis permanecer na Espanha, mesmo tendo recebido proteção e abrigo, além de oportunidade de fazer curso profissionalizante. Estava com saudades da filha $e$ arrependida de ter discutido com seus familiares. Recebeu orientação jurídica, social e telefone das autoridades brasileiras em seu Estado natal (Relatório, 20 de dezembro de 2007).

\section{Considerações finais}

A equipe do Posto trabalha com o fortalecimento do indivíduo de forma a emancipar o sujeito-vítima para sujeito de direitos, respeitando-se a dignidade da pessoa humana.

O Posto acolhe essas pessoas, dá informações e encaminha suas demandas, desde uma simples orientação sobre os trâmites dentro do aeroporto, até abrigamento e recâmbio, quando necessários. Entretanto, a experiência mostrou que ainda são raros os serviços capacitados para receber a vítima de tráfico ou a mulher migrante cujos direitos foram violados, serviços que contemplem, entre outras demandas, o atendimento psicológico e programas de reinserção social.

Vemos, no entanto, uma maior atenção dada ao tráfico de pessoas como crime que deve ser punido. $\mathrm{O}$ tratamento a suas vítimas é colocado em segundo plano. Para Kempadoo (2005:67):

Ao priorizar o crime, a punição e o controle da imigração, a abordagem do governo global diverge agora das perspectivas que foram geradas a partir de cuidados com a justiça social e os direitos humanos, particularmente das mulheres (...).

[Além disso]

problemas estruturais globais que produzem o tráfico globalização, patriarcado, racismo, conflitos e guerras étnicas, devastação ecológica e ambiental e perseguição política e religiosa - são raramente tocados no paradigma hegemônico sobre o tráfico. São esses problemas estruturais 
Direitos Humanos e gênero

que permanecem como fenômenos globais importantes para analisar, desconstruir e combater (Id., ib.: 68-69).

Da experiência do Posto, fica a percepção de que o debate sobre gênero, migração e tráfico de pessoas deve ser ampliado a fim de que sejam implementadas políticas públicas próximas à realidade e às necessidades dessas pessoas. Políticas com ações que tenham capilaridade, que sejam capazes de atingir municípios distantes de capitais. A estruturação dos Centros de Referência da Assistência Social (CRAS) e Centros de Referência Especializado da Assistência Social (CREAS), Centro de Referência da Mulher, além da implantação de novos centros, previstas no Plano Nacional de Enfrentamento ao Tráfico de Pessoas ${ }^{9}$, pode ser um caminho para iniciarmos a formação de uma rede de retaguarda capaz de atender mulheres migrantes cujos direitos tenham sido violados, traficadas ou não.

Além do Sistema Único de Assistência Social (SUAS), a equipe do Posto considera o Sistema Único de Saúde (SUS) como forte aliado no atendimento a essa demanda, além da atuação na prevenção ao tráfico de pessoas.

Além disso, é visível a necessidade de programas permanentes de sensibilização e capacitação de agentes públicos em tráfico de pessoas e gênero, a fim de que direitos não sejam violados de forma recorrente.

Por fim, é importante reiterar que o trabalho do Posto demonstrou que a situação dos/as deportados/as e inadmitidos/as, independente de apresentarem ou não indícios de tráfico de pessoas, precisa ser enfrentada com políticas públicas efetivas que garantam os direitos humanos desse público.

9 A Prioridade número 5 do PNETP é "Articular, estruturar e consolidar, a partir dos serviços já existentes, um sistema nacional de referência e atendimento às vítimas de tráfico" (Secretaria Nacional de Justiça, 2008:86-87). 
Asbrad

\section{Referências bibliográficas}

Aliança Global contra o Tráfico de Mulheres. Direitos Humanos $e$ Tráfico de Pessoas: um manual. Rio de Janeiro-RJ, GAATW, 2006.

FERREIRA, Rosário de Maria da Costa. Direitos Humanos e Sexualidade. Caderno de Conteúdo - Fortalecimento da rede de enfrentamento à violência sexual contra crianças e adolescentes, Guarulhos-SP, Associação Brasileira de Defesa da Mulher, da Infância e da Juventude (ASBRAD)/Secretaria Especial dos Direitos Humanos da Presidência da República (SEDH/PR), 2008.

KEMPADOO, Kamala. Mudando o debate sobre o tráfico de mulheres. Cadernos Pagu (25), Campinas-SP, Núcleo de Estudos de Gênero Pagu/Unicamp, 2005.

LisBOA, Tereza Kleba. Gênero e Migrações. Revista Interdisciplinar da Mobilidade Humana (26 e 27), Brasília-DF, Centro Scalabriano de Estudos Migratórios, 2006.

Massula, Letícia e Melo, Mônica de. Tráfico de Mulheres: Prevenção, punição e proteção. São Paulo, Consulado Geral dos Estados Unidos da América/CLADEM - Comitê da América Latina e do Caribe para a Defesa dos Direitos da Mulher, 2003.

PISCITELLI, Adriana. Sujeição ou Subversão? Migrantes brasileiras na indústria do sexo na Espanha. Revista História e Perspectivas (35), Uberlândia-MG, Universidade Federal de Uberlândia, 2006.

SECRETARIA NACIONAL DE JUSTIÇA. Política nacional de enfrentamento ao tráfico de pessoas. Brasilia-DF, SNJ, 2008.

- Pesquisas em Tráfico de Pessoas. Parte 3 - Tráfico internacional de pessoas e tráfico de migrantes entre deportad os/as e não admitid os/as que regressam ao Brasil via o aeroporto internacional de Guarulhos. Brasília, Secretaria Nacional de Justiça/OIT, 2007 (coord. Técnica: Adriana Piscitelli).

Pesquisas em tráfico de pessoas. Parte 2 - Relatório indícios de tráfico de pessoas no universo de deportadas e não admitidas que regressam ao Brasil via aeroporto de Guarulhos. Brasília, Secretaria Nacional de Justiça/OIT,2006 (coord. Técnica: Adriana Piscitelli). 